\title{
T cell subsets and expression of immunological activation markers in the arterial walls of patients with giant cell arteritis
}

\author{
RUNE ANDERSSON, ${ }^{1}$ ROLAND JONSSON ${ }^{2}$ ANDREJ TARKOWSKI, ${ }^{3}$ \\ BENGT-ÅKE BENGTSSON, AND BO-ERIC MALMVALL
}

From the ${ }^{1}$ Department of Infectious Diseases, Östra Hospital, University of Göteborg, Göteborg, Sweden; the ${ }^{2}$ Department of Oral Pathology, Faculty of Odontology, University of Göteborg, Göteborg, Sweden; the ${ }^{3}$ Departments of Medical Microbiology and Rheumatology, University of Göteborg, Göteborg, Sweden; the ${ }^{4}$ Department of Internal Medicine II, Sahlgrenska Hospital, University of Göteborg, Göteborg, Sweden; and the ${ }^{5}$ Department of Infectious Diseases, Jönköping Hospital, Jönköping, Sweden

SUMMARY Immunohistochemical features of infiltrating mononuclear cells (MNC) and resident cells were studied in the temporal artery biopsy specimens of 13 patients with histological verified giant cell arteritis (GCA) and in six biopsy specimens from patients with GCA with negative histological findings. Eight temporal artery biopsy specimens from seven patients with unrelated diseases served as controls. In all patients with GCA proved by biopsy an infiltration of T lymphocytes in the arterial wall was observed, most being of the helper/inducer subset. No B lymphocytes, or very few, were seen. Lymphocytes in 10 out of the 13 positive biopsy specimens displayed staining for the class II major histocompatibility complex (MHC) antigen HLA-DR, whereas this was found in only two of eight controls. A minor number of the infiltrating $T$ lymphocytes from seven out of 13 patients with GCA proved by biopsy stained for transferrin receptors, and in six out of the 13 cases they reacted with anti-interleukin 2 receptor antibody. In the arterial wall from all patients with histologically verified GCA we also found an increased number of macrophages, many of them expressing HLA-DR antigens and transferrin receptors. The immunohistochemical pattern of cell phenotypes found in the arterial wall of patients with GCA suggests that the infiltrating $T$ cells are immunologically activated. This finding supports the hypothesis of a predominantly cellular immunological pathogenesis of giant cell arteritis.

Key words: immunohistochemistry, T lymphocytes, interleukin 2 receptor, HLA-DR, transferrin receptor, macrophages, B lymphocytes, natural killer cells, polymyalgia rheumatica.

Giant cell arteritis (GCA) is a vascular disease of unknown aetiology. Both humoral and cellular mechanisms have been implicated in the pathogenesis of GCA. The hypothesis of GCA as a humoral, immunologically mediated disease is supported by the finding of immunoglobulin and complement deposits in the arterial walls. ${ }^{1-4}$ The demonstration of increased serum levels of IgG and complement and the detection of circulating immune complexes $^{5-8}$ also support this hypothesis. There is, however, some disagreement about the local

Accepted for publication 23 May 1987.

Correspondence to Dr Rune Andersson, Department of Infectious Diseases, Östra Hospital, University of Göteborg, S-41685 Göteborg, Sweden. immunoglobulin and complement deposits ${ }^{9}$ and the levels of serum immune complexes. ${ }^{10}$

In connection with the assumption of cell mediated immunity it should be noted that several authors have reported a decreased number of $T$ lymphocytes of the cytotoxic/suppressor subset in blood from patients with GCA. ${ }^{11-13}$ Elling and Elling found a connection between increased disease activity and the decreased numbers of cytotoxic/suppressor lymphocytes, ${ }^{12}$ which is in contrast with observations made by Benlahrache et al. ${ }^{11}$ No differences in lymphocyte antigenic responses between patients with GCA and normal controls have been found. ${ }^{14}$

Only limited and conflicting information is so far available about the phenotypes and activation status of lymphocytes in arterial lesions in GCA. 


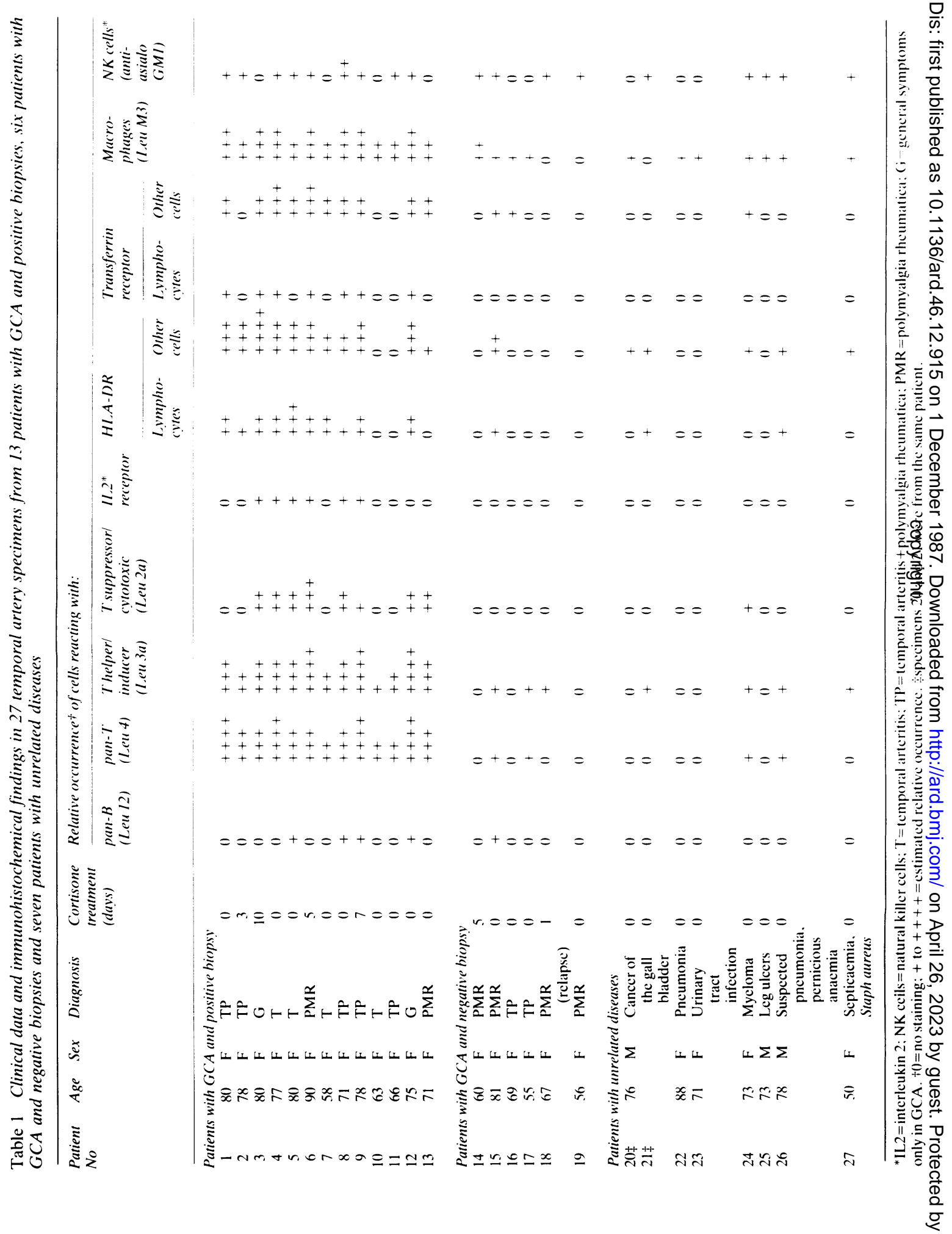


The aim of this study was to characterise the phenotypes of infiltrating $\mathrm{MNC}$ in the temporal arteries of patients with GCA and to study the prevalence of immunological activation markers on these cells.

\section{Patients and methods}

PATIENTS

Twenty seven temporal artery specimens from 26 patients were studied. The biopsies were performed during the years 1982-6 at the department of otorhinolaryngology at Östra Hospital in Göteborg. The patients were treated at the departments of internal medicine and infectious diseases. Thirteen of the biopsy specimens showed histological signs of giant cell arteritis (i.e., positive biopsy) on examination by routine light microscopy. Six patients had giant cell arteritis according to clinical criteria ${ }^{15}$ but a negative biopsy. As controls, we used eight biopsy specimens from seven patients who proved to have other, unrelated diseases. In none of the biopsy specimens from patients with GCA were signs of any significant atherosclerotic process found. Clinical features of all patients included in the study are summarised in Table 1.

The patients with GCA were divided into the following clinical groups, as previously described ${ }^{15}$ : (a) localised temporal arteritis $(\mathrm{T})$; $(b)$ polymyalgia rheumatica (PMR); (c) temporal arteritis and polymyalgia rheumatica (TP); and (d) general symptoms (G) with no clinical symptoms from the temporal area or proximal muscles.

\section{METHODS}

The biopsy specimens were transported to the laboratory in a buffered medium (Histocon, Göteborg, Sweden), were rapidly frozen with dichlorodifluoromethane spray, and stored at $-70^{\circ} \mathrm{C}$.

The following monoclonal antibodies were used: anti-Leu 4 (CD3), anti-Leu 3a (CD4), anti-Leu 2a (CD8), anti-Leu 12 (CD19), anti-Leu M3 (CD14), and anti-transferrin receptor (Becton and Dickinson, Sunnyvale, CA, USA); anti-HLA-DR and antiinterleukin 2 receptor (CD25) (Dakopatts, Glostrup, Denmark); anti-asialo GM1 (Wako, Osaka, Japan). Anti-Leu 4 detects all $T$ cells, anti-Leu 3a reacts with the helper/inducer $T$ cell subset, and anti-Leu $2 \mathrm{a}$ reacts with the suppressor/cytotoxic $T$ cell subset. Anti-Leu 12 reacts with all B lymphocytes, anti-Leu M3 with the macrophages, and anti-asialo GM1 with the natural killer (NK) cells. Serial sections from the arteries $(6 \mu \mathrm{m}$ thick) were prepared in a cryostat. The sections were fixed in cold acetone for five minutes, washed in phosphate buffered saline (PBS), and endogenous peroxidase blocked by treatment with $0.3 \% \mathrm{H}_{2} \mathrm{O}_{2}$ for 10 minutes. After additional washes in PBS the sections were incubated for 30 minutes in a humidified chamber at room temperature with $50 \mu \mathrm{l}$ portions of monoclonal antibodies diluted in PBS containing $4 \%$ bovine serum albumin (PBS-BSA). Biotin labelled antimouse immunoglobulin (Vector Laboratories, Burlingame, CA, USA) diluted in PBS-BSA was used as the secondary reagent. Binding of biotin labelled antibodies was detected after incubation with avidin-biotin-peroxidase complexes (Vector) ${ }^{16}$ and by subsequent use of $\mathrm{H}_{2} \mathrm{O}_{2}$ and a buffer containing 3-amino-9-ethylcarbazole. All sections were counterstained with Mayer's haematoxylin.

\section{Results}

The immunohistochemical findings are presented in Table 1 and Figs 1 and 2. In all the patients with GCA and a positive artery biopsy on routine microscopy we found an abundant infiltration of MNC, most of them reactive with Leu 4 (pan-T) antibody. Most of these cells expressed the helper/ inducer (Leu 3a) phenotype. A minor portion of the MNC expressed the suppressor/cytotoxic (Leu 2a) phenotype. The anti-Leu $3 \mathrm{a}$ antibody reacts not only with $\mathbf{T}$ lymphocytes but also with some nonlymphocytic cells. ${ }^{17} 18$ It was possible, however, to estimate the number of lymphocytes stained with anti-Leu 3a by the cell morphology. No B lymphocytes, or only a few, were found, as ascertained by negative staining with anti-Leu 12 .

The MNC in 11 out of the 13 positive biopsy specimens showed staining for HLA-DR antigen. The prevalence of stained MNC corresponded with the degree of inflammation as assessed by the amount of infiltrating cells. Both lymphocytes and some of the cells in close connection with the infiltrating lymphocytes were stained. The distribution of macrophages was similar to the expression of HLA-DR antigen, indicating that a large proportion of the non-lymphoid HLA-DR positive cells were probably macrophages. In five out of the eight control biopsy specimens expression of HLA-DR antigen was infrequently observed.

Staining for transferrin receptor was visible on some of the $T$ cells in seven out of the 13 patients with positive biopsies but none of the eight controls. Transferrin receptor stain was also found diffusely around the fragmented internal elastic lamina. Some of the transferrin receptor positive cells had the morphological appearance of macrophages (Figs 1d and $e$ ), and in serial sections the similar cells were stained with anti-Leu M3. The prevalence of interleukin 2 receptors displaying lymphocytes was low in six out of 13 positive biopsy specimens. A low 
918 Andersson, Jonsson, Tarkowski, Bengtsson, Malmvall

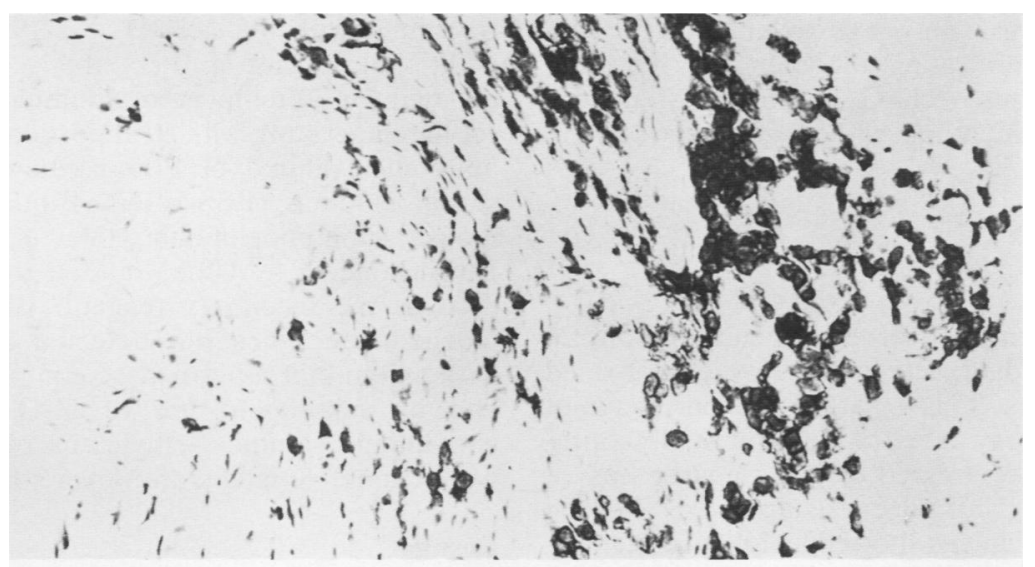

Fig. 1a

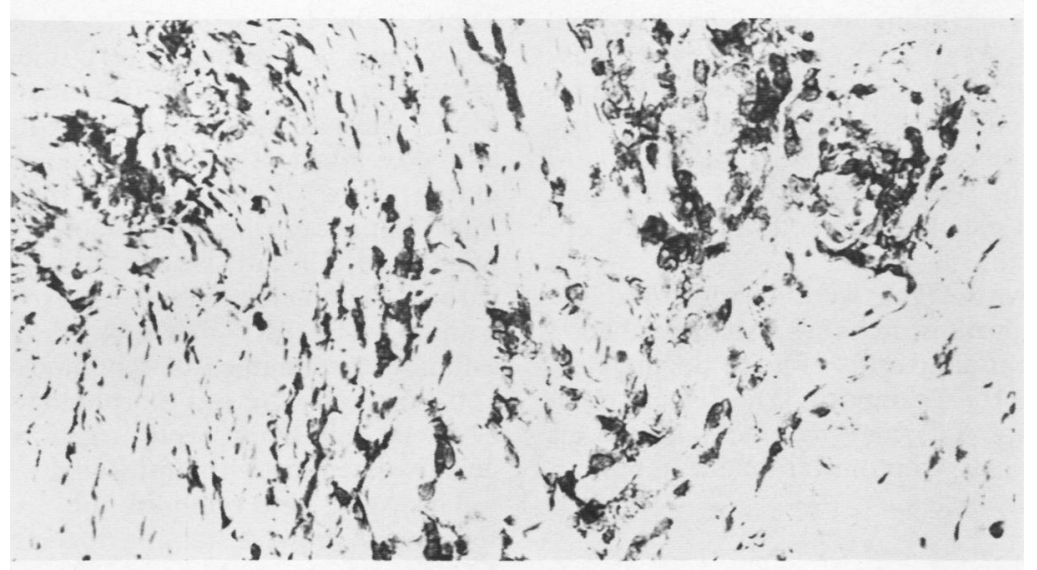

Fig. 1b

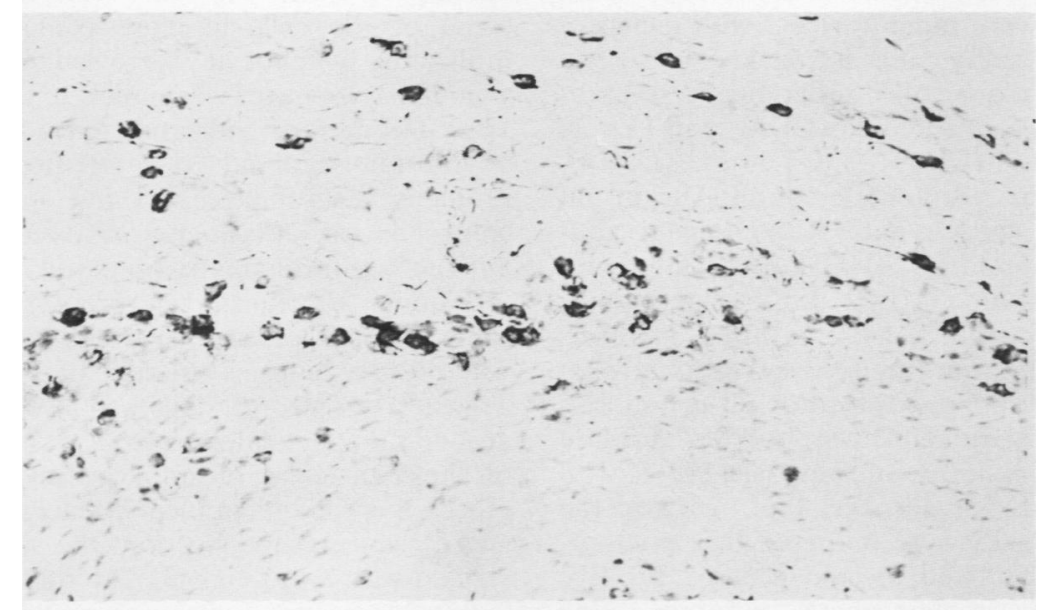

Fig. 1c 


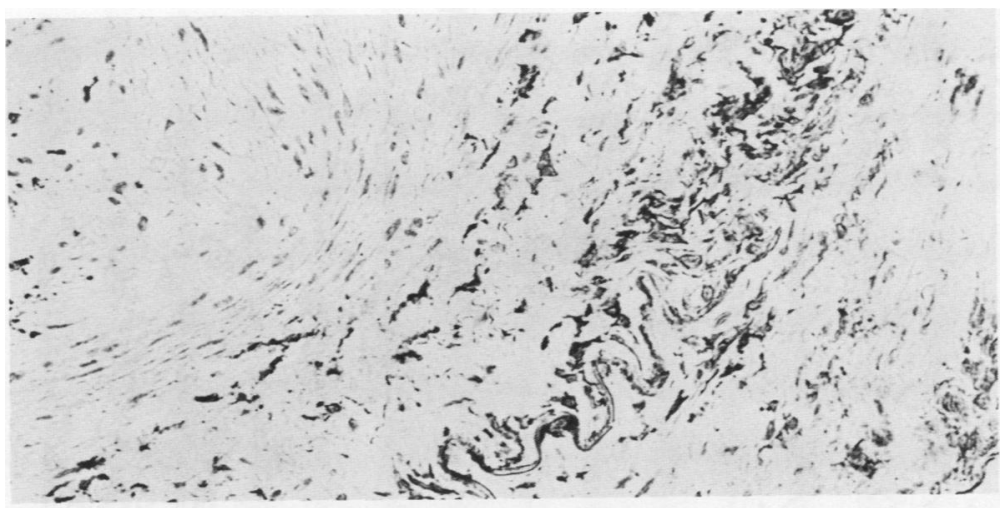

Fig. 1d

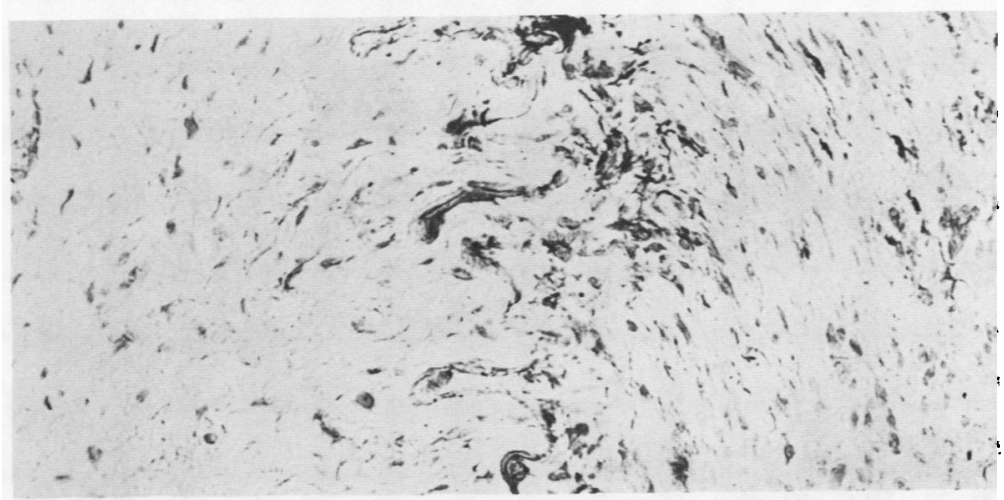

Fig. 1e

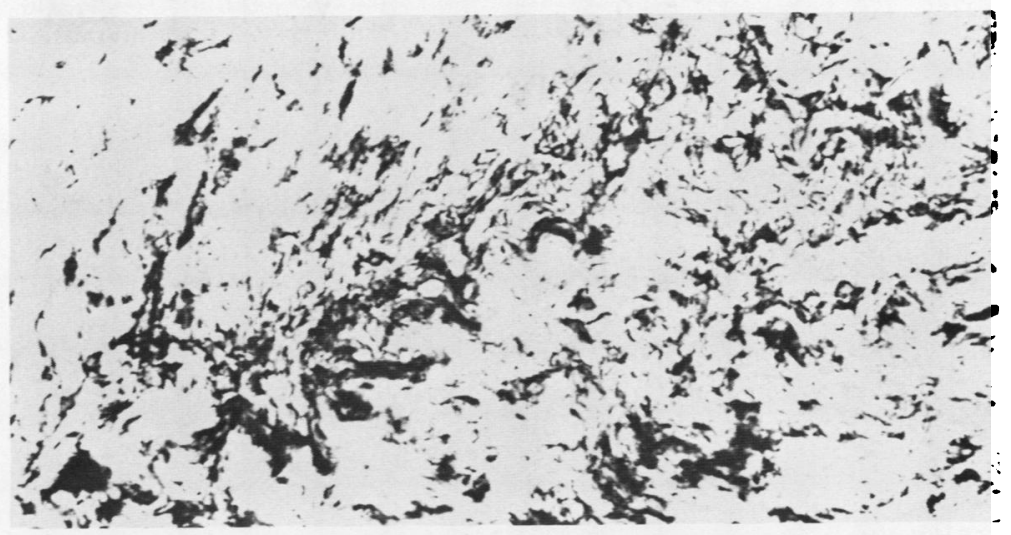

Fig. 1f

Fig. 1 Immunoperoxidase staining of the temporal artery from an 80 year old woman with giant cell arteritis (patient No 3) using monoclonal antibodies against (a) Leu 4=all T lymphocytes; (b) Leu 3a=helper/inducer T lymphocytes;

(c) Leu 2a=suppressor/cytotoxic T lymphocytes; (d) Leu M3=macrophages; (e) transferrin receptor; (f) HLA-DR. 
920 Andersson, Jonsson, Tarkowski, Bengtsson, Malmvall

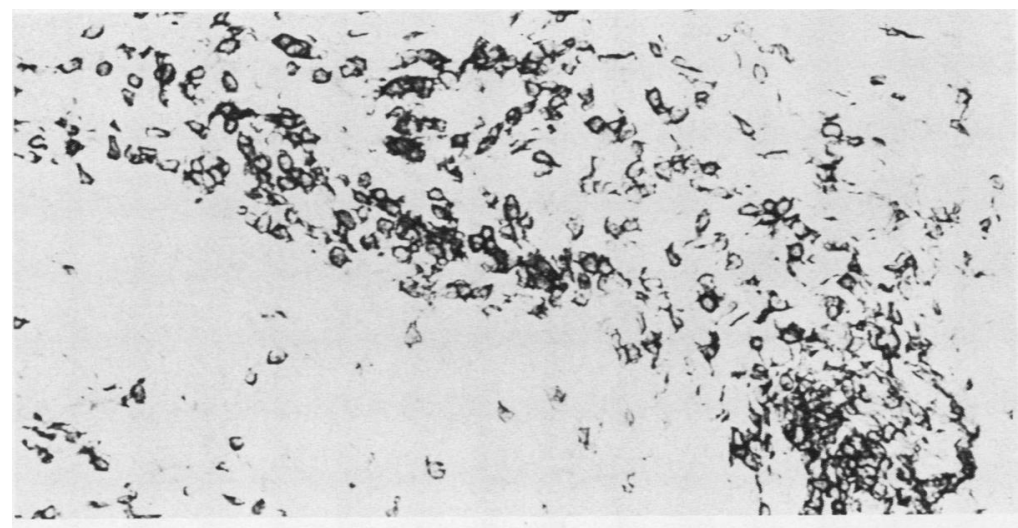

Fig. 2a

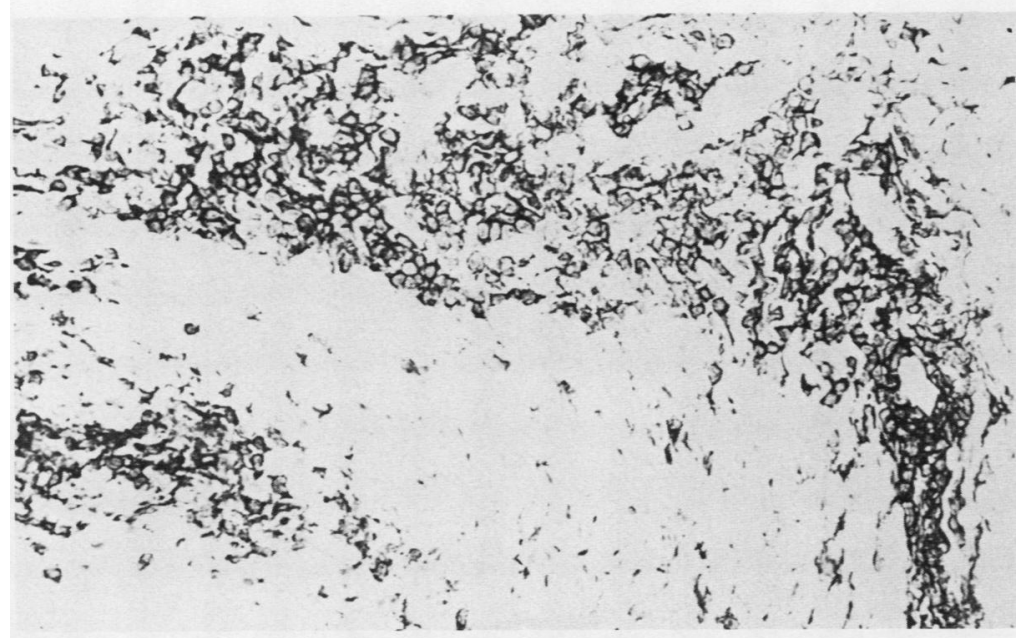

Fig. 2b

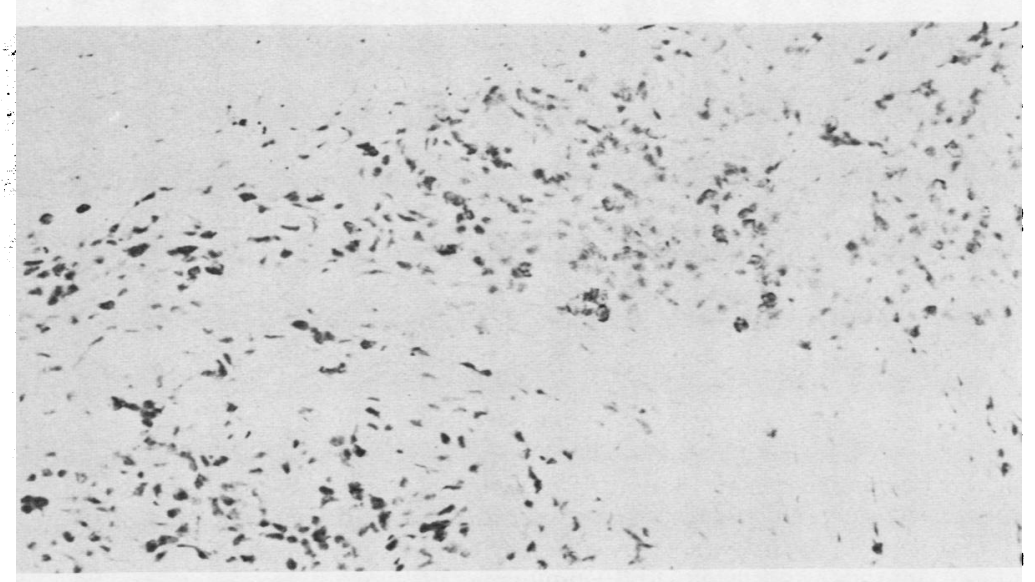

Fig. $2 \mathrm{c}$ 


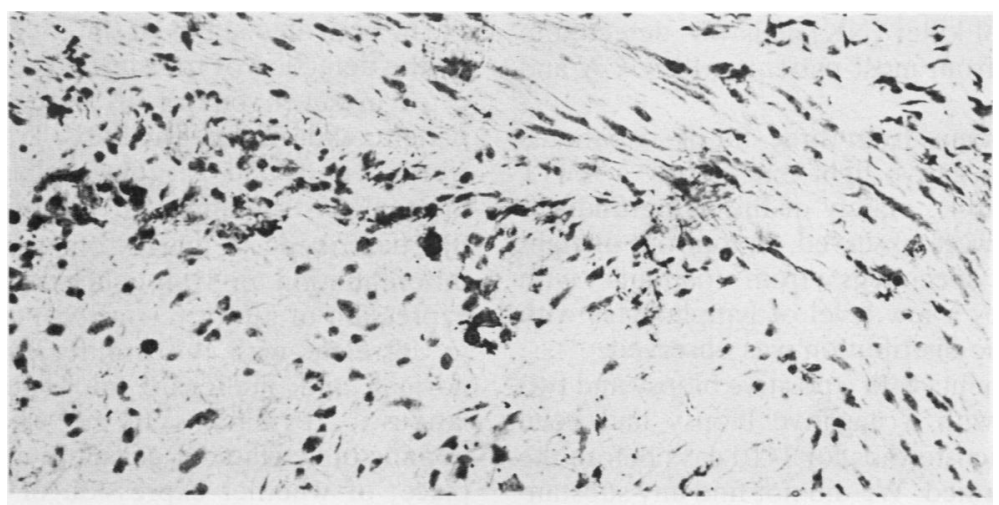

Fig. $2 d$

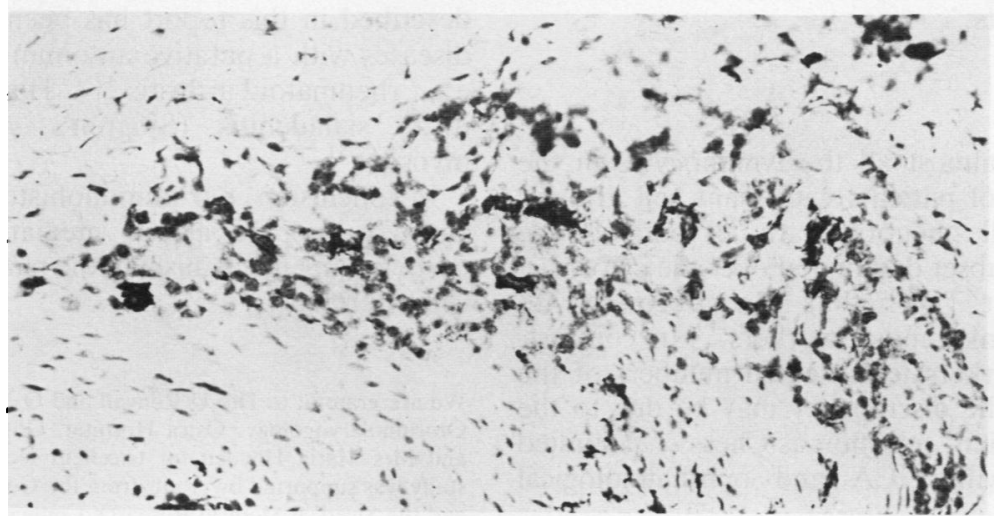

Fig. 2e

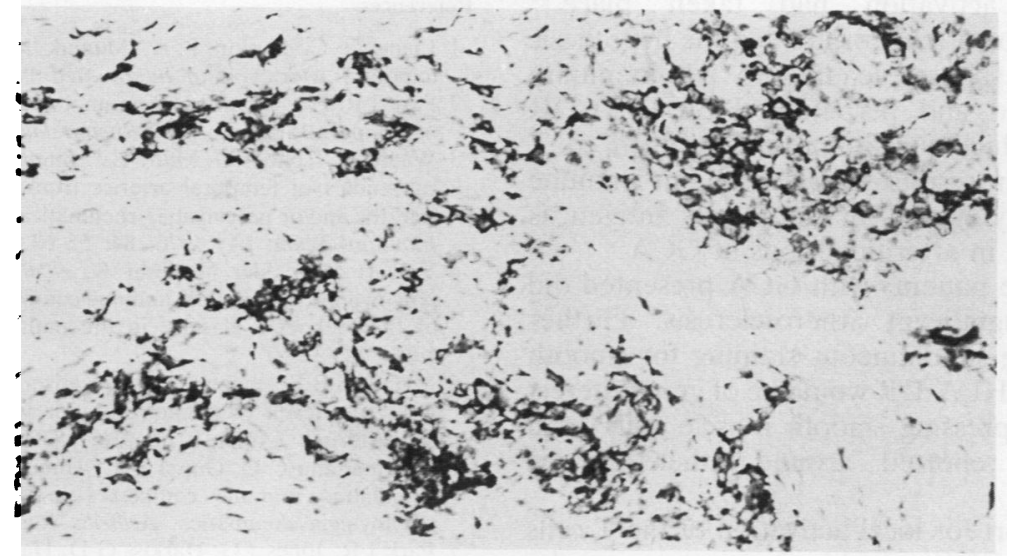

Fig. $2 f$

Fig. 2 Immunoperoxidase staining of the temporal artery from a 75 year old woman with giant cell arteritis (patient No 12) using monoclonal antibodies against (a) Leu 4=all T lymphocytes; (b) Leu 3a=helperlinducer T lymphocytes;

(c) Leu $2 a=$ suppressor/cytotoxic $T$ lymphocytes; (d) Leu M3=macrophages;

(e) transferrin receptor; (f) $H L A \cdot D R$. 
number of natural killer (NK) cells was detected in the arterial wall from most patients with GCA and most controls.

In biopsy specimens from three out of six patients with GCA and negative light microscopy a few T lymphocytes (Leu 4), mainly of the helper/inducer (Leu 3a) subset, were observed. In four out of eight control biopsy specimens from patients with unrelated diseases a low level of lymphocytes with similar phenotypic distribution was observed.

Four of the patients with a positive biopsy and two of the patients with a negative biopsy had been treated with corticosteroids for 1-10 days before the biopsy was performed. We did not find any substantial differences for the phenotype markers of the lymphocytes in arterial specimens from treated and untreated patients.

\section{Discussion}

We found that almost all the lymphocytes in the arteritic lesions of patients with giant cell arteritis expressed $\mathrm{T}$ cell phenotype. In all patients the helper/inducer subset dominated over the cytotoxic/ suppressor subset. This finding is in agreement with the work of Banks and coworkers. ${ }^{19}$ In contrast, Chess and coworkers found equal numbers of the two subsets. ${ }^{20}$ The discrepancy may be due to the difference in patient selection as Chess et al studied only patients with GCA and ophthalmological symptoms.

A large number of the $\mathrm{MNC}$ in the arteritic lesions expressed HLA-DR antigens, indicating that immunological activation had taken place. ${ }^{21}$ Klareskog and coworkers formulated the hypothesis that immune responses leading to autoimmunity may be initiated and perpetuated by HLA-DR positive cells which locally present antigen to $T$ cells. ${ }^{22}$ Thus our results suggest that an immune reaction, possibly against an autologous antigen, is occurring locally in arteritic lesions of GCA.

In none of the patients with GCA presented did we find any significant atherosclerosis. Further studies including simultaneous staining for smooth muscle cells and HLA-DR would be of great interest as HLA-DR expressing smooth muscle cells have recently been reported around atherosclerotic plaques. ${ }^{23-25}$

Further support for local activation of the T cells was the finding of interleukin 2 receptors on the lymphocytes in six out of 13 biopsy specimens with signs of arteritis. As interleukin 2 receptor expression is a prerequisite of subsequent IL2 binding and activation of $T$ cells ${ }^{26}$ our findings further emphasise that lymphocytes found in arteritic lesions are stimulated.
The activated status of the T cells was also shown $\frac{}{\rho}$. by the detection of transferrin receptors on lymphocytes in seven out of 13 biopsy specimens from $\overrightarrow{\vec{F}}$ patients with giant cell arteritis. Transferrin receptors were also found on macrophages close to the internal elastic lamina. The transferrin receptor was $\frac{\bar{\omega}}{\omega}$ first described as a marker of an early stage of T cell $\widehat{\nabla}$ differentiation in lymphoblastic leukaemia. ${ }^{27}$ The expression of a transferrin receptor has been found to correlate with the proliferation status in both $\vec{\circ}$ normal and malignant mononuclear cell popu- $\overrightarrow{\vec{\omega}}$ lations. ${ }^{28}$ It remains to be established whether $\stackrel{\sigma}{\mathscr{\omega}}$ homing of activated $\mathrm{T}$ cells into arteritic areas takes place, or whether expression of IL2R, transferrin receptor, and HLA-DR is induced in situ.

An immunohistochemical pattern similar to that $\vec{N}$ described in this report has been found in several $\stackrel{0}{0}$ diseases with a putative autoimmune pathogenesis, $G$ e.g., rheumatoid arthritis, ${ }^{17}{ }^{29}$ Hashimoto's thyroid- $\frac{}{7}$ itis, ${ }^{30}$ sialadenitis (Sjögren's syndrome), ${ }^{18}$ and $\overrightarrow{7}$ myositis. $^{31}$

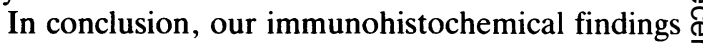
strongly support a cell mediated, possibly self $\underset{\square}{Z}$ perpetuating mechanism in the pathogenesis of giant $\stackrel{\mathbb{D}}{-}$ cell arteritis.

We are grateful to Drs U Renvall and O Nyhlén, Department Otorhinolaryngology, Östra Hospital, Göteborg for the biopsies and Mrs Maria Heyden for excellent technical assistance. This study was supported by grants from the Göteborg Medical Society and the Swedish Medical Research Council (No 7338).

\section{References}

1 Liang G C, Simkin P A, Mannik M. Immunoglobulins in temporal arteries. Ann Intern Med 1974; 81: 19-24.

2 Park J R, Hazleman B L. Immunological and histological studyஹ of temporal arteries. Ann Rheum Dis 1978; 37: 238-43.

3 Waaler E, Tönder $\mathrm{O}$, Milde E J. Immunological and histologi-O cal studies of temporal arteries from patients with temporal arteritis and/or polymyalgia rheumatica. Acta Pathol Microbiolo Immunol Scand [A] 1976; 84: 55-63.

4 Velvart $M$, Felder $M$, Fehr $K$, et al. Temporal arteritis in polymyalgia rheumatica: immune complex deposits and the role윽 of the leukocyte elastase in the pathogenesis. $Z$ Rheumatol $>$ 1983; 42: 320-7.

5 Malmvall B E, Bengtsson B Å, Kaijser B, Nilsson L Å, Alestig $K$. Serum levels of immunoglobulin and complement in giant $N$ cell arteritis. JAMA 1976; 236: 1876-8.

6 Papaioannou C C, Gupta R C, Hunder G G, McDuffie F C. N Circulating immune complexes in giant cell arteritis and N polymyalgia rheumatica. Arthritis Rheum 1980; 23: 1021-5. $\omega$

7 Park J R, Jones J G, Harkiss G D, Hazleman B L. Circulating immune complexes in polymyalgia rheumatica and giant cello arteritis. Ann Rheum Dis 1981; 40: 360-5.

8 Youinou P Y, Pennec Y, Tande D, LeMenn G. Immunec complexes and autoantibodies in patients with giant cell arteritis: and their relationship with autologous rosette-forming cells. T Clin Exp Rheumatol 1985; 3: 17-21.

9 Gallagher $\mathbf{P}$, Jones $\mathrm{K}$. Immunohistochemical findings in cranial ${ }^{\Phi}$ arteritis. Arthritis Rheum 1982; 25: 75-9. 
10 Malmvall B E, Bengtsson B $\AA$, Nilsson L $\AA$, Bjursten L M. Immune complexes, rheumatoid factors and cellular immunological parameters in patients with giant cell arteritis. Ann Rheum Dis 1981; 40: 276-80.

11 Benlahrache C, Segund P, Auquier L, Bouvet J P. Decrease of OKT 8 positive T-cell subset in polymyalgia rheumatica. Lack of correlation with disease activity. Arthritis Rheum 1983; 26: 1472-80

12 Elling H, Elling P. Decreased level of suppressor/cytotoxic T cells $(\mathrm{OKT} 8+)$ in polymyalgia rheumatica and temporal arteritis: relation to disease activity. $J$ Rheumatol 1985; 12: 306-9.

13 Chelazzi G, Broggini M. Abnormalities of peripheral blood T lymphocyte subsets in polymyalgia rheumatica. Clin Exp Rheumatol 1984; 2: 333-6.

14 Papaioannou C C, Hunder G G, McDuffie F C. Cellular immunity in polymyalgia rheumatica and giant cell arteritis. Lack of response to muscle or artery homogenates. Arthritis Rheum 1979; 22: 740-5.

15 Bengtsson B $\AA$, Malmvall B E. The epidemiology of giant cell arteritis including temporal arteritis and polymyalgia rheumatica. Incidences of different clinical presentations and eye complications. Arthritis Rheum 1981; 24: 899-904.

16 Hsu S M, Raine L, Fanger H. Use of avidin-biotin-peroxidase complexes $(\mathrm{ABC})$ in immunoperoxidase techniques. A comparison between $\mathrm{ABC}$ and unlabelled antibody (PAP) procedures. J Histochem Cytochem 1981; 29: 577-80.

17 Lindblad S, Klareskog L, Hedfors E, Forsum U, Sundström C. Phenotypic characterization of synovial tissue cells in situ in different types of synovitis. Arthritis Rheum 1983; 26: 1321-32.

18 Lindahl G, Hedfors E, Klareskog L, Forsum U. Epithelial HLA-DR expression and $T$ lymphocyte subsets in salivary glands in Sjögren's syndrome. Clin Exp Immunol 1985; 61: 475-82.

19 Banks P M, Cohen M D, Ginsburg W W, Hunder G G. Immunohistologic and cytochemical studies of temporal arteritis. Arthritis Rheum 1983; 26: 1201-7.

20 Chess J, Albert D M, Bhan A K, et al. Serologic and immunopathologic findings in temporal arteritis. Am J Ophthalmol 1983; 96: 283-9.

21 Mann D L, Sharrow S O. HLA-DRw alloantigens can be detected on peripheral blood T lymphocytes. J Immunol 1980; 125: $1889-96$.

22 Klareskog L, Forsum U, Scheynius A, Kabelitz D, Wigzell H. Evidence in support of a self-perpetuating HLA-DR dependent delayed-type cell reaction in rheumatoid arthritis. Proc Natl Acad Sci USA 1982; 79: 3632-6.

, 23 Jonasson L, Holm J, Skalli O, Gabbiani G, Hansson G K. Expression of class II transplantation antigen on vascular smooth muscle cells in human atherosclerosis. J Clin Invest 1985; 76: $125-31$.

24 Jonasson L, Holm J, Skalli O, Bondjers G, Hansson G K. Regional accumulations of T-cells, macrophages and smooth muscle cells in the human atherosclerotic plaque. Arteriosclerosis 1986; 6: 131-8.

25 Hansson G K, Jonasson L, Holm J, Claesson-Welsh L. Class II $\mathrm{MHC}$ antigen expression in the atherosclerotic plaque: smooth muscle cells express HLA-DR, HLA-DQ and the invariant gammachain. Clin Exp Immunol 1986; 64: 261-8.

26 Leonard W J, Depper J M, Uchiyama T, Smith K A, Waldman T A, Greene W C. A monoclonal antibody that appears to recognize the receptor for human T-cell growth factor; partial characterization of the receptor. Nature 1982; 300: 267-9.

27 Reinherz E L, Kung P C, Goldstein G, Levey R H, Schlossman $S$ F. Discrete stages of human intrathymic differentiation: analysis of normal thymocytes and leukemic lymphoblasts of $\mathrm{T}$ cell lineage. Proc Natl Acac Sci USA 1980; 77: 1588-92.

28 Sutherland R, Delia D, Schneider C, Newman R, Kemshead J, Greaves M. Ubiquitous cell-surface glycoprotein on tumor cells is proliferation-associated receptor for transferrin. Proc Natl Acad Sci USA 1981; 78: 4515-9.

29 Klareskog L, Forsum U, Wigren A, Wigzell H. Relationships between HLA-DR-expressing cells and $T$ lymphocytes of different subsets in rheumatoid synovial tissue. Scand J Immunol 1982; 15: 501-7.

30 Jansson R, Karlsson A, Forsum U. Intrathyroidal HLA-DR expression and $\mathrm{T}$ lymphocyte phenotypes in Graves' thyrotoxicosis, Hashimoto's thyroiditis and nodular colloid goitre. Clin Exp Immunol 1984; 58: 264-72.

31 Olsson T, Henriksson K G, Klareskog L, Forsum U. HLA-DR expression, T-lymphocyte phenotypes, OKM1 and OKT9 reactive cells in inflammatory myopathy. Muscle Nerve 1985; 8: 419-25. 